\title{
Pelatihan Kewirausahaan Berbasis Iptek untuk Membina Ibu Rumah Tangga yang Produktif di Kelurahan Lolong- Belanti, Padang
}

\author{
Prima Fithri, Lusi Susanti, Difana Meilani, Suci Rahmawati, dan Ulfa Nadiatur Rahmi \\ Fakultas Teknik, Universitas Andalas, Kampus Limau Manis, Padang, 25163. Indonesia \\ E-mail: primafithri@eng.unand.ac.id
}

Keywords:

entrepreneurship, unemployment, women

Kata Kunci: Kewirausahaan, pengangguran, perempuan

\begin{abstract}
The polemic of unemployed women is getting worse because in choosing a job, women often think about work that does not interfere with their routine as housewives. In addition, there is also a labor market that does not accept female workers, either single or married, for reasons that are sometimes illogical. Even though the abilities and skills of women are no less good and there are no differences with men. This is also a major factor why many women are unemployed. As a result, it becomes a factor of poverty. Given the importance of this problem, it is necessary to implement ways to overcome them, especially in reducing the number unemployment. The solution to this problem is quite easy, as long as it is given a job, the unemployment problem will be resolved. However, in practice it is not that easy. To open new jobs requires substantial funds, in addition to funds, it is necessary to provide entrepreneurship training for the unemployed so that the unemployed have skills capital in the world of work to be involved. As a scientific discipline, entrepreneurship can be studied and taught, so that every individual has the opportunity to appear as an entrepreneur (entrepreneur). Even to be a successful entrepreneur, having talent is not enough, you also need to have knowledge of all aspects of the business that you will be engaged in. The tasks of entrepreneurship are very many, including the task of making decisions, technical leadership, and leadership, therefore facilities and infrastructure are needed, one of which is education.
\end{abstract}
ABSTRAK
Polemik perempuan pengangguran semakin menjadi-jadi, karena perempuan dalam memilih pekerjaan sering memikirkan pekerjaan yang tidak mengganggu rutinitasnya sebagai ibu rumah tangga. Di samping itu, juga ada pasar tenaga kerja yang tidak menerima tenaga kerja perempuan, baik yang belum menikah maupun yang sudah menikah dengan alasan yang kadang-kadang tidak logis. Mengingat pentingnya masalah tersebut kiranya perlu diadakan cara penanggulangan terutama dalam mengurangi jumlah pengangguran, yaitu melakukan pelatihan kewirausahaan untuk ibu-ibu rumah tangga khususnya. Metode yang dilakukan adalah metode ceramah dan diskusi. Peserta pelatihan yaitu 20 orang ibu-ibu rumah tangga kelurahan lolong belanti. Pelatihan ini sangat berguna bagi mereka karena dapat menciptakan lapangan kerja baru. Akan tetapi kendala yang dihadapi adalah terkait modal dan peralatan yang akan digunakan. Kendala tersebut dapat menjadikan program kegiatan pengabdian selanjutnya sehingga output akhirnya inkubasi bisnis dapat dilakukan. 


\section{PENDAHULUAN}

Jumlah penduduk Sumatera Barat saat ini mendekati 2.5 juta jiwa (Badan Pusat Statistik Nasional, 2018). Hampir setiap tahun terjadi peningkatan angkatan kerja, baik yang berijazah maupun yang tidak. Namun sayangnya, kurang diimbangi dengan pemenuhan lapangan kerja. Di era globalisasi ini, sudah menjadi hal yang tidak asing ketika kita mendengar kata "pengangguran", sering kita mendengar keluhan dari orang yang tidak mendapat atau mempunyai pekerjaan. Sebagian besar dari para pencari kerja lebih memilih mencari kerja sebagai tujuan utama daripada berwirausaha. Semakin banyaknya pencari kerja dan sempitnya lowongan kerja, perusahaan yang membutuhkan karyawan cenderung mempunyai standar kualitas sumber daya manusia yang tinggi. Kualitas sumber daya manusia menentukan keberhasilan kerja dan memperoleh pekerjaan. Kualitas sumber daya manusia sangat dipengaruhi oleh karakteristik atau sifat-sifat yang mendukung.

Sementara itu aktivitas kewirausahaan (entrepreneurial activity) di negara kita dewasa ini tergolong rendah. Ini ditunjukkan oleh jumlah individu yang aktif dalam memulai bisnis baru jika dinyatakan dalam persen total penduduk yang aktif bekerja relatif masih rendah. Keadaan ini mengakibatkan angka pengangguran tinggi sehingga jumlah penduduk miskin juga bertambah. Pengangguran juga diramaikan oleh remaja wanita dan ibu-ibu rumah tangga.

Dari data Pusat Statistik Sumatera Barat 2018 menunjukkan, jumlah angkatan kerja di Sumatera Barat semakin meningkat dari tahun ke tahun. Perekonomian Indonesia sejak krisis ekonomi pada pertengahan 1997 membuat kondisi ketenagakerjaan Indonesia ikut memburuk (Hendrawati, 2016). Sejak itu, pertumbuhan ekonomi Indonesia juga tidak pernah mencapai 7-8 persen. Padahal, masalah pengangguran erat kaitannya dengan pertumbuhan ekonomi. Jika pertumbuhan ekonomi ada, otomatis penyerapan tenaga kerja juga ada. Setiap pertumbuhan ekonomi satu persen, tenaga kerja yang terserap bisa mencapai 400 ribu orang. Jika pertumbuhan ekonomi Indonesia hanya 3-4 persen, tentunya hanya akan menyerap 1,6 juta tenaga kerja, sementara pencari kerja mencapai rata-rata 2,5 juta pertahun. Sehingga, setiap tahun pasti ada sisa pencari kerja yang tidak memperoleh pekerjaan dan menimbulkan jumlah pengangguran di Indonesia bertambah.

Tingkat pengangguran perempuan terus meningkat dari tahun ke tahun, namun belum ada solusi yang tepat untuk mengatasinya, sehingga potret kemiskinan semakin merajalela, dimana perempuan yang menjadi tumpuan keluarga tidak sepenuhnya mampu memenuhi kebutuhan hidup mereka. Sebenarnya banyak hal yang dapat dilakukan perempuan untuk mengatasi pengangguran yaitu menjadi seorang wirausahawati sejati yang bisa membuka lowongan kerja bagi diri sendiri dan juga perempuan lainnya.

Polemik perempuan pengangguran semakin menjadi-jadi karena perempuan dalam memilih pekerjaan sering memikirkan pekerjaan yang tidak mengganggu rutinitasnya sebagai ibu rumah tangga. Di samping itu, juga ada pasar tenaga kerja yang tidak menerima tenaga kerja perempuan, baik yang belum menikah maupun yang sudah menikah dengan alasan yang kadangkadang tidak logis. Padahal kemampuan dan skill perempuan tak kalah bagusnya dan juga tak ada perbedaan dengan laki-laki. Ini juga menjadi faktor utama mengapa banyak perempuan yang menganggur. Akibatnya, menjadikan salah satu faktor kemiskinan (Franita, 2016; Probosiwi, 2016; Wardiansyah \& Bahri, 2016).

Di samping tentu saja faktor utama kemiskinan adalah miskin ilmu (pengetahuan) dan etos kerja. Ibarat seperti lingkaran setan: kebodohan dan kemiskinan, karena bodoh sehingga jadi miskin, karena miskin sehingga jadi bodoh. Situasi ini agaknya hanya bisa diputus mata rantainya yaitu dengan pendidikan yang berkualitas. Dengan pendidikanlah seseorang bisa meningkatkan kualitas dirinya dari kebodohan menuju kepintaran, dari kemiskinan ke kekayaan. 
Karena pendidikan yang kurang menyebabkan Mind set yang salah dalam memandang kehidupan, termasuk kekayaan dan kemajuan. Hal ini menyebabkan paradigma berpikir seseorang cenderung fatalisme (pasrah pada nasib/takdir) tak mau berusaha. Di sini pendidikan tidak harus diartikan pendidikan formal (berijazah) dan berada di ruang kelas, tetapi yang substansial adalah pendidikan atau pengetahuan bagi pengembangan diri untuk kemajuan dan kesejahterannya seperti life skills (keterampilan hidup).

Selain tingkat pendidikan dan pengetahuan warganya, kemajuan ekonomi suatu negara atau daerah juga dipengaruhi oleh infrastruktur yang tersedia di wilayahnya. Karena infrastruktur yang ada akan sangat mendukung tingkat kemajuan ekonomi sebuah negara seperti kebijakan pemerintah, sarana transportasi, jalan, jembatan penghubung daerah terisolir, dan lainnya. Sehingga dibutuhkan suatu kreatifitas dari masyarakat saat ini agar terhindar dari pengangguran, hal yang pasti bisa dilakukan adalah berwirausaha. Jika dahulu kewirausahaan merupakan bakat bawaan sejak lahir dan diasah melalui pengalaman langsung di lapangan, maka sekarang ini paradigma tersebut telah bergeser karena masyarakat yang tidak berbakat dan semua orang bisa melakukannya. Kewirausahaan telah menjadi suatu disiplin ilmu yang mempelajari tentang nilai, kemampuan (ability) dan perilaku seseorang dalam menghadapi tantangan hidup untuk memperoleh peluang dengan berbagai resiko yang mungkin dihadapinya.

Setiap tahun jumlah pengangguran kian menumpuk. Sebenarnya mereka termasuk kelompok usia yang konsumtif dan belum produktif. Hal itu tentu akan menghambat pertumbuhan karena pertambahan pendapatan sebagian besar akan habis dikonsumsi oleh orang yang masih menganggur atau belum bekerja. Jika hal itu dibiarkan terus-menerus jumlah pengagguran semakin besar dan pada suatu saat dapat menjadi boomerang dalam pembangunan. Hal semacam itu tentu tidak kita inginkan.

Di dalam mengurangi jumlah pengangguran terlepas dari kualitasnya yang rendah, minimal para pengangguran tersebut harus diberi lapangan pekerjaan sesuai dengan masing-masing bidang. Dengan demikian, status pengangguran yang tadinya merupakan manusia yang konsumtif, akan bergeser menjadi manusia yang produktif. Hal itu akan mempunyai dampak yang sangat positif bagi pembangunan yaitu (Mantra,2000):

1. Akan mengurangi beban ketergantungan (dependency ratio);

2. Meningkatkan pendapatan atau kesejah teraan masyarakat.

Penganggur tersebut pada umumnya bukan tidak mau bekerja, melainkan sulit mendapatkan pekerjaan.

Mengingat pentingnya masalah tersebut kiranya perlu diadakan cara penanggulangan terutama dalam mengurangi jumlah pengangguran. Pemecahan masalah ini cukup mudah yaitu asal diberikan pekerjaan selesailah masalah pengangguran tersebut. Akan tetapi di dalam pelaksanaannya tidaklah semudah itu. Untuk membuka lapangan pekerjaan baru memerlukan dana yang cukup besar, selain dana perlu diberikan pelatihan kewirausahaan pada pengangguran agar para pengangguran mempunyai modal keterampilan dalam dunia kerja yang akan digeluti.

Sebagai suatu disiplin ilmu, maka ilmu kewirausahaan dapat dipelajari dan diajarkan, sehingga setiap individu memiliki peluang untuk tampil sebagai seorang wirausahawan (entrepreneur). Kewirausahaan merupakan suatu ilmu yang sangat penting dan dapat menciptakan pekerjaan baru (Hilyati Milla, 2010; Zimmerer \& Scarborough, 2008). Bahkan untuk menjadi wirausahawan sukses, memiliki bakat saja tidak cukup, tetapi juga harus memiliki pengetahuan segala aspek usaha yang akan ditekuninya. Tugas dari wirausaha sangat banyak, antara lain tugas mengambil keputusan, kepemimpinan teknis, dan kepemimpinan, oleh karena itu dibutuhkan sarana dan prasarana, salah satunya pendidikan. 
Tujuan kegiatan ini adalah untuk melatih Ibu-ibu Rumah Tangga (IRT) bagaimana menjadi wirausaha yang benar, sehingga dapat memerikan penghasilan tambahan untuk para IRT tersebut. Pelaksanaan kegiatan pelatihan ini meliputi:

a. Mengidentifikasi permasalahan yang muncul dengan di lingkungan tersebut

b. Merancang modul kewirausahaan untuk panduan para IRT tersebut

c. Memberikan pelatihan kepada IRT Kelurahan Lolong-Belanti

Manfaat yang diperoleh dari kegiatan ini adalah dengan adanya pelatihan ini diharapkan nantinya para IRT dapat memanfaatkan waktunya untuk berwirausaha sehingga dapat memberikan penghasilan tambahan.

\section{METODE}

Kegiatan Pelatihan Kewirausahaan ini dilakukan di Kantor PBHI Provinsi Sumatera Barat Kelurahan Lolong Belanti Padang. Sasaran atau target yang menjadi peserta pelatihan ini adalah bu-ibu Rumah Tangga di kelurahan Lolong Belanti Padang yang mempunyai potensi untuk menciptakan lapangan pekerjaan sendiri. Pada kegiatan ini, kita memberikan materi tentang kewirausahaan, bagaimana berwirausaha yang semestinya disesuaikan dengan perkembangan zaman.

Metode yang dilakukan adalah dengan ceramah dan diskusi. Adapun rencana kegiatan yang telah disusun adalah sebagai berikut dapat dilihat pada Tabel 1 dibawah ini.

Tabel 1. Kegiatan yang telah dilaksanakan

\begin{tabular}{|l|l|l|l|l|l|l|l|l|l|l|}
\hline \multirow{2}{*}{ No } & \multicolumn{7}{|c|}{ Kegiatan } & \multicolumn{7}{|c|}{ Bulan Pelaksanaan } & \multirow{2}{*}{ Penanggung Jawab } \\
\cline { 3 - 11 } & & 1 & 2 & 3 & 4 & 5 & 6 & 7 & 8 & \\
\hline 1. & Survei Pendahuluan & $\mathrm{X}$ & $\mathrm{X}$ & & & & & & & Prima, Lusi, Difa \\
\hline 2. & $\begin{array}{l}\text { Koordinasi dengan Ketua RT } \\
\text { di Kelurahan Lolong Belanti }\end{array}$ & & $\mathrm{X}$ & $\mathrm{X}$ & & & & & & Prima \\
\hline 3. & $\begin{array}{l}\text { Pelatihan kewirausahaan } \\
\text { kepada ibu-ibu rumah tangga } \\
\text { di Kelurahan Lolong Belanti }\end{array}$ & & $\mathrm{X}$ & $\mathrm{X}$ & $\mathrm{X}$ & $\mathrm{X}$ & & & & Prima, Lusi, Difa \\
\hline 4. & Pendampingan dan konsultasi & & & & & & & $\mathrm{X}$ & $\mathrm{X}$ & Prima, Lusi, Difa \\
\hline
\end{tabular}

\section{HASIL DAN PEMBAHASAN}

\section{A. Pelaksanaan Kegiatan}

Kegiatan pengabdian dilakukan pada hari Minggu, tanggal 25 Oktober 2015. Pada kegiatan ini dilakukan pelatihan kepada ibu-ibu rumah tangga di Kelurahan Lolong Belanti. Adapun dalam melakukan pelatihan, peserta melewati beberapa langkah-langkah berikut ini:

\section{Registrasi Peserta}

Kegiatan pengabdian ini dimulai pada jam 08.00 WIB, diawali dengan menandatangani absen yang telah disediakan. Pada pelatihan ini, peserta yang diharapkan hadir adalah Ibu-ibu Rumah Tangga Kelurahan Lolong Belanti yang sudah memiliki usaha maupun yang belum memiliki usaha, akan tetapi mempunyai keinginan untuk mendirikan usaha sendiri. Peserta yang hadir pada pelatihan ini sekitar 20 orang dan terdiri dari ibu-ibu rumah tangga yang tinggal di sekitar kelurahan lolong belanti. Pada umumnya ibu-ibu tersebut tamatan SMA. Kegiatan ini 
dilakukan atas izin Ketua RT setempat karena perlu dan butuhnya keterampilan akan kewirausahaan bagi ibu-ibu rumah tangga tersebut.

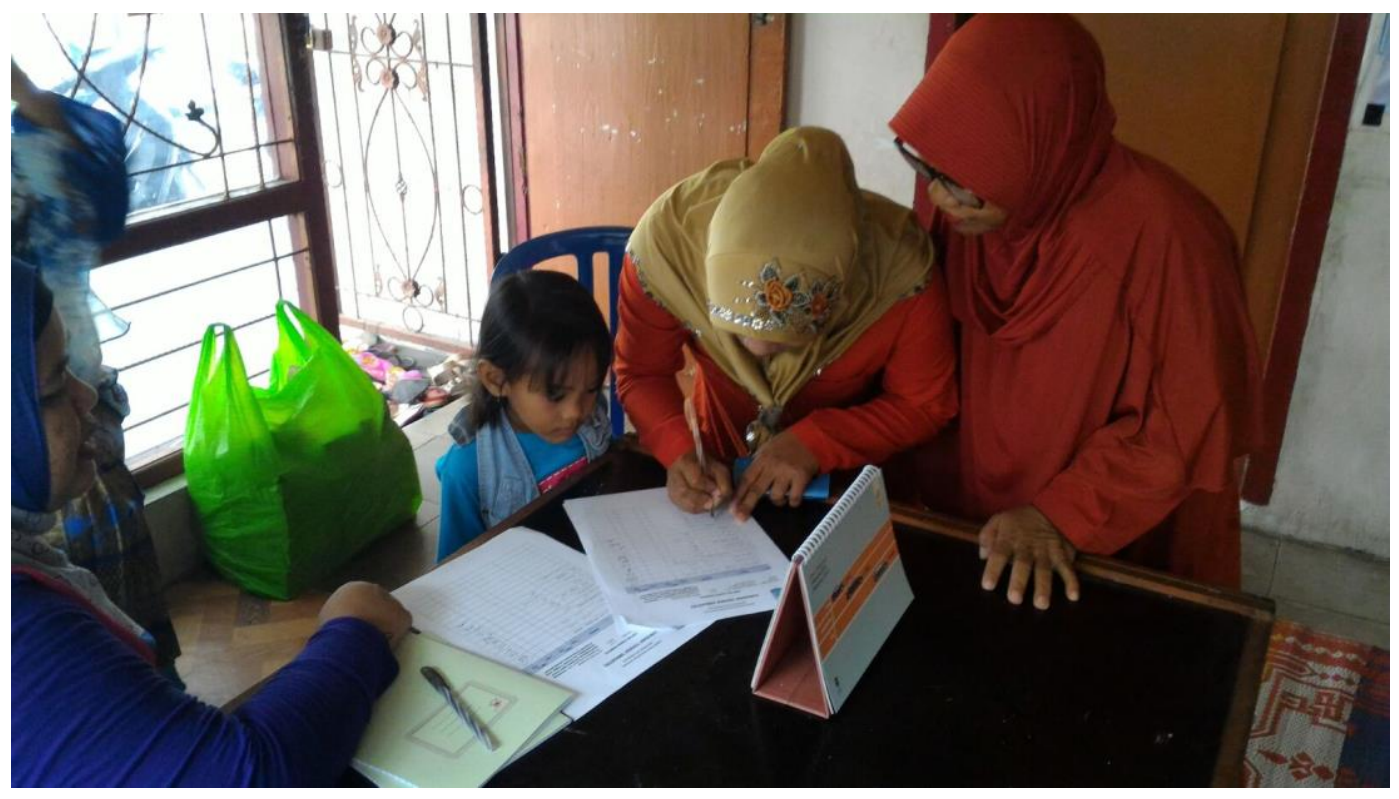

Gambar 1. Peserta menandatangani absen

\section{Pelatihan Kewirausahaan}

Pada kegiatan ini, setelah peserta memenuhi kuota yang diinginkan, maka kami memulai pelatihan kewirausahaan dengan melakukan kegiatan awal yaitu survei kepada peserta tentang apakah semua peserta menginginkan dirinya mendirikan suatu usaha. Setelah dilakukan survei, ternyata $88 \%$ peserta menyatakan sangat ingin mendirikan suatu usaha sendiri. Hal ini dapat dilihat pada Gambar 2 dibawah ini.

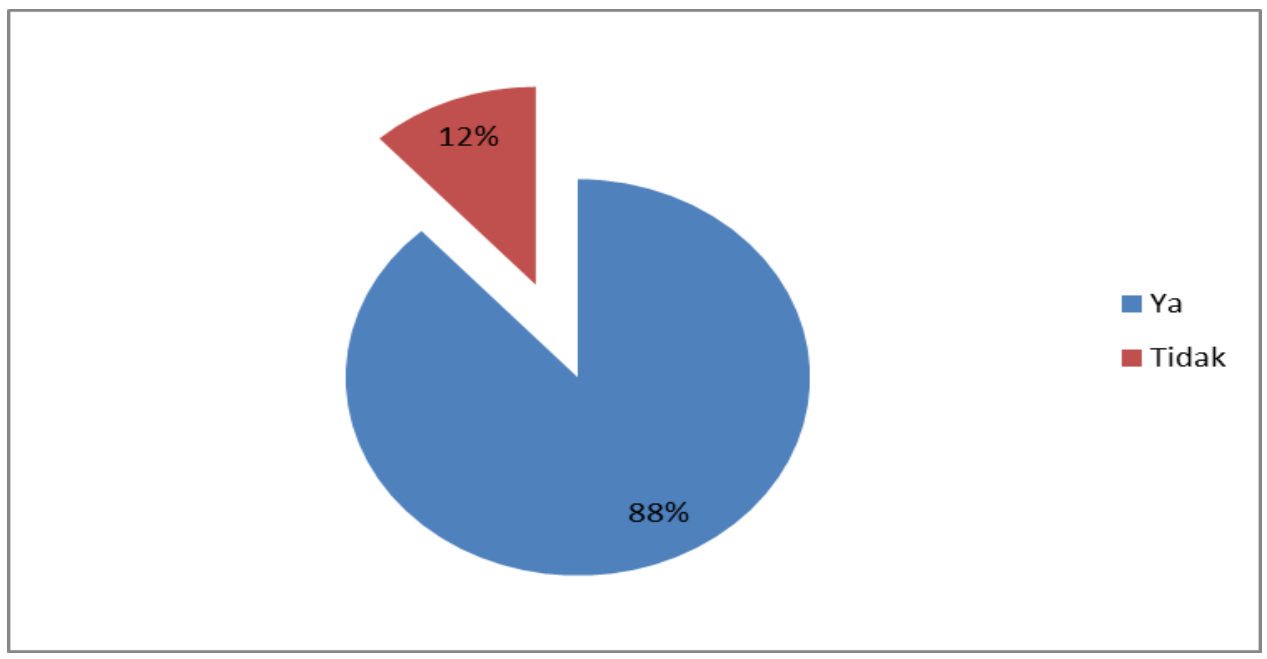

Gambar 2. Minat peserta untuk mendirikan usaha

Tidak heran memang masih ada peserta yang masih ragu untuk mendirikan usaha sendiri, hal ini juga banyak disebabkan oleh hal-hal seperti tidak adanya modal, kurangnya pengetahuan akan wirausaha, kurangnya ilmu komunikasi. Jika diketahui dari data survei kepada para peserta, penyebab yang paling meragukan peserta untuk mendirikan sebuah usaha adalah tidak 
adanya modal dasar untuk mendirikan sebuah usaha yang diinginkannya. Hal ini dapat terlihat pada gambar 3 dibawah ini.

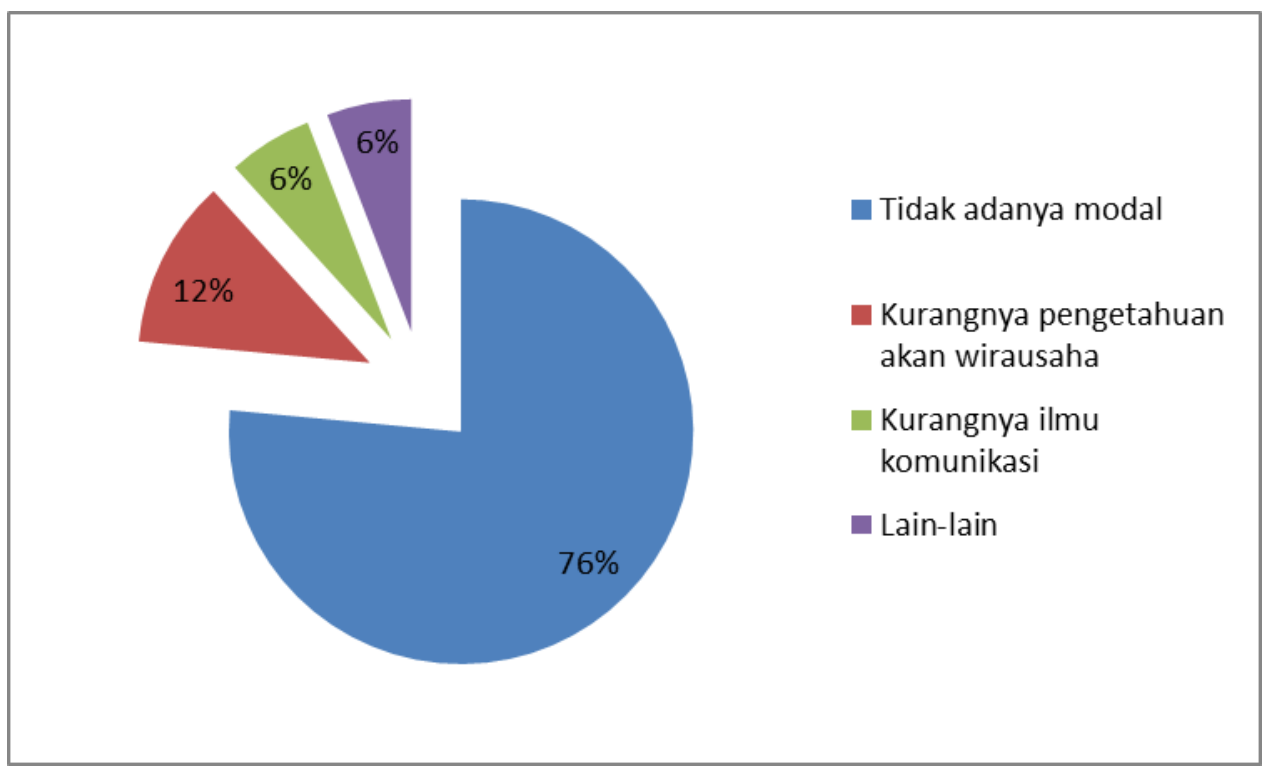

Gambar 3. Penyebab peserta ragu untuk mendirikan Usaha

Untuk membentuk jiwa yang mempunyai keinginan dalam mendirikan usaha sendiri, maka Tim Pengabdian berusaha melakukan hal-hal sebagai berikut :

1. Memberikan motivasi kepada peserta bahwa untuk menjadi wirausaha tidak hanya membutuhkan modal, akan tetapi ide untuk menjadikan sesuatu yang tidak ada nilai gunanya, menjadi sesuatu yang bernilai guna.

2. Memberikan contoh-contoh wirausaha yang berhasil di Indonesia sebagai pembanding bagi peserta untuk mendirikan usaha

3. Memberikan cara-cara jitu yang dapat dilakukan untuk mendirikan usaha yaitu diantanya adalah dengan memanfaatkan kemajuan teknologi yaitu internet.

Pada pelatihan ini, Tim memberikan contoh-contoh kemajuan teknologi yang dapat digunakan oleh peserta sebagai cara untuk mendirikan usaha dan sekaligus mempertahankan usaha yang telah didirikan. Pada zaman era globalisasi sekarang ini, siapa yang tidak mengenal internet, bahkan ibu rumah tangga sekalipun. Untuk mendapatkan akses internet pun pada saat ini tidaklah susah. Selain dengan handphone sebagai media penyalur internet yang dapat dijangkau harganya, untuk paket internet juga tidaklah mahal. Dari data yang ada, sekitar 85\% peserta memiliki handphone yang sudah bisa untuk akses internet.

Adapun internet yang digunakan adalah bentuknya menggunakan media sosial sebagai alat untuk mengembangkan usaha, mendirikan dan mempertahankan usaha. Zaman sekarang siapa yang tidak mengenal media sosial seperti facebook, instagram, dan path. Seperti terlihat pada gambar 4 dibawah ini. Media sosial dirasa tidak hanya untuk update status atau memberitahukan kita sedang berada dimana. Akan tetapi media sosial sudah banyak digunakan orang sebagai alat untuk mendirikan suatu usaha, promosi, dan mempertahankan usahanya. 


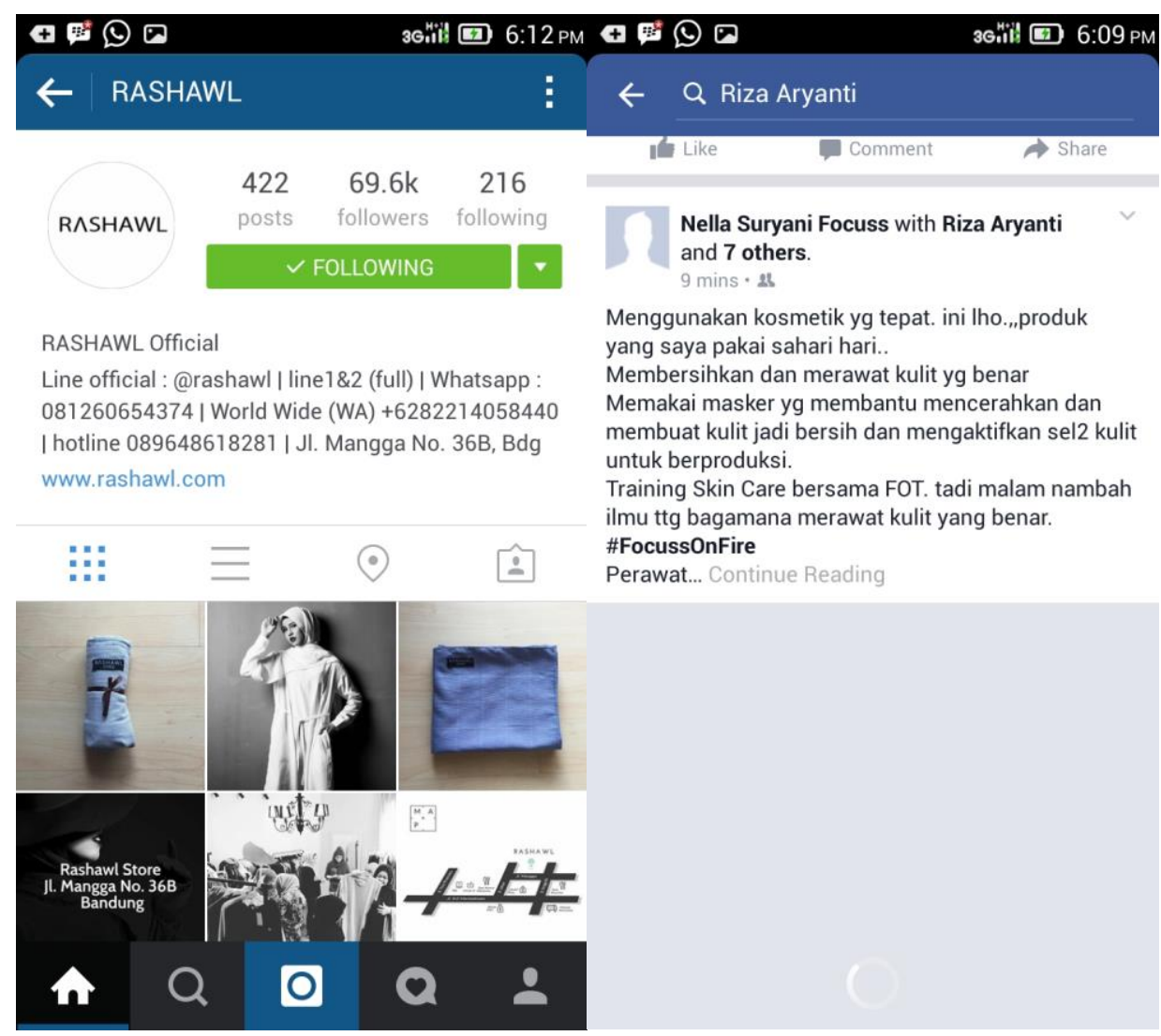

Gambar 4. Media Sosial yang dapat digunakan (Instagram dan Facebook)

Peserta diajarkan untuk menggunakan media sosial dengan baik khususnya untuk berwirausaha. Bagi peserta yang sudah mempunyai akun sendiri, mereka akan dengan mudah menggunakan media sosialnya. Adapun langkah-langkah yang dapat dilakukan peserta sangatlah sederhana, yaitu :

1. Peserta mengunggah foto produk yang akan dijual ke media sosial mereka sendiri.

2. Dengan foto yang telah diunggah, peserta melampirkan keterangan produk misalnya harga, bahannya, ukurannya, dan sebagainya. Hal ini tergantung kepada produk yang akan kita pasarkan.

3. Peserta dapat menunggu komentar dari pembeli sembari melakukan aktivitas lain, seperti memasak, menjemput anak dari sekolah.

Dengan langkah-langkah diatas, peserta merasa semangat kembali untuk mendirikan usaha tanpa harus memiliki modal yang besar. Tetapi memanfaatkan ide, kemajuan teknologi dan kerjasama dengan pihak lain.

Untuk penyempurnaan kegiatan ini dilakukan survei terhadap peserta yang telah mengikuti pelatihan ini. Dan hasilnya peserta sangat antusias dengan kegiatan yang dilakukan, akan tetapi untuk menerapkannya mereka memiliki kendala dalam hal modal dan peralatan. Untuk itu kegiatan selanjutnya akan dilakukan untuk mengadakan peralatan pendukung seperti untuk kelompok menjahit, akan mengadakan peralatan mesin jahit agar dapat digunakan ibu-ibu rumah tangga tersebut secara bergantian. 


\section{KESIMPULAN DAN SARAN}

\section{Kesimpulan}

Dari kegiatan Pelatihan Kewirausahaan Berbasis Iptek Untuk Menghasilkan Ibu Rumah Tangga Yang Produktif di Kelurahan Lolong-Belanti yang telah dilaksanakan dapat ditarik beberapa kesimpulan sebagai berikut:

1. Peserta Pelatihan memahami pentingnya kewirausahaan untuk meningkatkan perekonomian peserta.

2. Masing-masing peserta telah mendapatkan pemahaman bagaimana melakukan kewirausahaan dengan menyesuaikan pada zaman saat ini.

\section{Saran}

Beberapa saran yang dapat diajukan meliputi:

1. Diusulkan adanya kegiatan pendampingan yang dilaksanakan berbagai instansi terkait dengan pembinaan kewirausahaan bagi ibu rumah tangga yang tidak bekerja.

2. Adanya pemberian alat yang dapat digunakan bersama dalam menciptakan suatu wirausaha seperti mesin jahit, alat pemaanggang kue, dan lain-lain.

3. Untuk kegiatan selanjutnya dapat dilakukan dengan mengaplikasikan kewirausahaan tersebut dan menginkubasi bisnisnya.

\section{UCAPAN TERIMA KASIH}

Terima kasih kepada seluruh pihak yang telah terlibat dalam kegiatan ini. Ucapan terima kasih juga disampaikan kepada Jurusan Teknik Industri Universitas Andalas telah memberikan dana pengabdian ini.

\section{DAFTAR PUSTAKA}

Badan Pusat Statistik Nasional. (2018). Jumlah Penduduk Indonesia Tahun 2018. Http://Datastatistik-Indonesia.Com.

Franita, R. (2016). Analisa Pengangguran Di Indonesia. Jurnal Ilmu Pengetahuan Sosial.

Hilyati Milla. (2010). Pendidikan Kewirausahaan : Hilyati, Pendidikan Kewirausahaan.

Probosiwi, R. (2016). Pengangguran dan Pengaruhnya terhadap Tingkat Kemiskinan. Balai Besar Penelitian Dan Pengembangan Pelayanan Kesejahteraan Sosial (B2P3KS).

Wardiansyah, M., \& Bahri, Z. (2016). Analisis faktor-faktor yang mempengaruhi tingkat pengangguran (Studi kasus provinsi-provinsi se-Sumatera). Jurnal Ekonomi Sumberdaya Dan Lingkungan.

Zimmerer, T. W., \& Scarborough, N. M. (2008). Kewirausahaan dan Manajemen Usaha Kecil. In Salemba Empat. https://doi.org/10.1017/CB09781107415324.004 